\section{Kadıini Mağarası Geç Kalkolitik/ Erken Tunç Çağı İskelet Topluluğunun Demografik Analizi}

\author{
N. Damla YILMAZ USTA ${ }^{1 *}$
}

' Dr. Öğr. Üyesi, Süleyman Demirel Üniversitesi, Antropoloji Bölümü, Isparta/TÜRKIYE

$\ddot{\mathrm{O} z}$

Antalya ilinin Alanya ilçesinde yer alan Kadıini Mağarası'ndan Alanya Müzesi Bașkanlığı’nda 2017 yllında gerçekleștirilen kurtarma çalıșmalarında Geç Kalkolitik / Erken Tunç Çağı’na tarihlendirilen insan iskelet kalıntıları gün yüzüne çıkarılmıştır. Bu çalışmada minimum 90 bireyin olduğu tespit edilen Kadiini topluluğunun demografik özelliklerinin analiz edilmesi amaçlanmıştır. Kadinni topluluğunda bebek ve çocukların (15 yaş altı) ölüm oranı \%37,78'dir. Toplulukta onarlı yaş aralıklarına göre en yüksek ölüm oranı (dx: \%35,56) 10-19 yaş grubundadır. 0-9 yaş grubu, ölüm oranının $(\% 22,22)$ görece az; yaşam beklentisinin ise ( $e^{0} \mathrm{x}: 19,56$ yll) en yüksek görüldüğü dönemdir. Ortalama yaşam uzunluğu (15+ yaş; 25,9 yıl), Anadolu Kalkolitik ve Tunç Çağı toplumları arasında değerlendirildiğinde düşüktür. Toplulukta 40 yaştaki yaşam beklentisi $\left(\mathrm{e}^{0} \mathrm{x}\right)$ 5 yll gibi az bir süredir ve 50 yaş üzerinde yaşayan bireye rastlanmamıştır. Kadınların ortalama yaşam uzunluğu (24,5 yıl) erkeklere göre (26,8 yll) azdır. Toplulukta 45 yaş üzerinde hayatta kalma şansı (Ix) ve yaşam beklentisi $\left(\mathrm{e}^{0} \mathrm{x}\right)$, kadın bireylerde sonlanırken erkek bireylerde (Ix: \%11,54; $\mathrm{e}^{0} \mathrm{x}$ : 5yll) az oranda da olsa devam etmektedir. Demografik bulgulardan Kadinininin genç ve büyüyen nüfusa sahip bir topluluk olduğu, bununla birlikte Anadolu'nun bazı tarihöncesi toplumlarında olduğu gibi yaşam şartlarından kadınların daha fazla etkilendiği söylenebilir.

Anahtar Sözcükler: Paleodemografi, ortalama ölüm yaşı, yaşam uzunluğu, hayatta kalma şansı, yaşam beklentisi

\section{Giriş}

Demografibelirli bir bölgede belirli bir zaman sürecinde yaşayan insanların nüfusunu inceler (Erdal, 1993; Aksu, 1998). Demografik veriler sağlık, yaşam alanı, doğal kaynaklar, geçim ekonomisi, beslenme rejimi, genetik özellikler, iklim, bitki örtüsü, topografya, bazı kültürel uygulamalar gibi biyolojik, sosyal ve çevresel faktörlerle ilișkili olduğundan toplumların ilgili faktörlerle etkileşimlerini, yaşam şartlarına dirençlerini ve uyarlanma başarılarını göstermesi açısından önemlidir (Howel, 1976; Hopa, 2002; Signoli vd., 2002; Neustupný, 2004; Chamberlain, 2006; Caussinus ve Courgeau, 2010).

Abstract expectancy.
* Sorumlu Yazar / Corresponding Author: N. Damla Yılmaz Usta Süleyman Demirel Üniversitesi, Fen - Edebiyat Fakültesi Antropoloji Bölümü, Ofis 352 32260 Merkez, Isparta / TÜRKIYE E-posta: nalanyilmazusta@sdu.edu.tr

Alındı/Received: 25 Subat / February 2019 Düzeltildi/Revised: 9 Aralık / December 2019 Kabul/Accepted: 11 Aralık / December 2019 Yayımlandı/Published: 20 Aralık / December 2019

Demographical Analysis of the Late Chalcolithic/Early Bronze Age Skeletal Population in Kadini Cave

In the rescue works carried out by the Alanya Museum in 2017 in the Kadini Cave in the Alanya district of Antalya province, the buman skeleton remains dating to the Late Chalcolithic / Early Bronze Age were unearthed. The minimum number of individuals among these skeletal remains was 90. A total of 90 individuals were examined in order to analyze the demographic characteristics of the buman skeletons. In the Kadiini community, the mortality rate of infants and children is $37,78 \%$. According to the age groups at the life table, the bighest mortality rate in the community ( $d x: 35,56 \%$ ) is the 10-19 age group. In the 0-9 age group, mortality rate is a relatively low $(22,22 \%)$ but life expectancy rate is the highest (e $e^{0}: 19,56$ years). The longevity for adults (15+ age; 25,9 years) is low when evaluated among some Anatolian Chalcolithic and Bronze Age populations. The life expectancy at age $40\left(e^{0} x\right)$ in the community is as low as 5 years and no individual living above 50 years old has been found. The longevity for women (24,5 years) is shorter than it is for men (26,8 years). The life expectancy among surviving individuals who are over 45 years of age in the community ended in women but continued in male (Ix: 11,54\%; $e^{0} x$ : 5years). The demographic findings exbibit that Kadiini was probably a community with a young and growing population, also that the women were probably more affected by living conditions as seen in some prehistoric societies of Anatolia.

Key Words: Paleodemography, mean age at death, longevity, survivors entering, life

Neolitik Çağ'dan itibaren yerleşik hayata geçişle birlikte yeni yaşam biçimine uyarlanmayla doğurganlığın, ölümlülüğün ve göç hareketlerinin artmasina paralel olarak nüfus özelliklerinin değişmeye başladığ1 bilinir (Acsadi ve Nemeskeri, 1970; Angel, 1972, 1975, 1984; Özbek, 1998, 2004; Özbek ve Erdal, 2006; Alpaslan-Roodenberg, 2008b; Koca Özer vd., 2008; Hillson vd., 2013; Larsen vd., 2015; Büyükkarakaya, 2017). Günümüz (Aksu, 1998; Akın ve Ersoy, 2012; Türkiye İstatistik Kurumu [TÜIK], 2012a, 2016) ve eski toplumları araştıran çalışmalarda (Acsadi ve Nemeskeri, 1970; Güleç, 1988, 1989; Arman, 1991; Sevim, 1993; Açıkkol, 2000; Hopa ve Vaupel, 2002; 
Gözlük Kırmızıŏ̆lu, 2005; Güleç vd., 2007; Eshed vd., 2008; Güleç ve Özer, 2009; Açıkkol Yıldırım, 2013; Hillson vd., 2013; Müller, 2015) demografik özelliklerin toplumların yaşam şartlarıyla, dolayısıyla biyokültürel uyarlanmalarıyla doğrudan ilişkili olduğunun altı çizilir. Toplumların uyarlanma başarılarına çevresel özellikler, geçim ekonomisi, beslenme rejimleri, temizlik alışkanlıkları, kültürel davranış biçimleri gibi yaşam şartlarını belirleyen birbiriyle bağlantılı birçok etmen etki etmekle birlikte bunlar doğrudan veya dolaylı olarak onların demografik yapilarına yansır (Signoli vd., 2002; Neustupný, 2004; Chamberlain, 2006; Caussinus ve Courgeau, 2010). Günümüz toplumları üzerinde yürütülen araştırmalarda, sağllk durumu ve sosyal refahtaki iyileşmeye paralel nüfus dinamiklerinin değişerek doğurganlığın, ölümlülüğün ve nüfus artış oranlarının azalma, yaşam süresinin ise artma eğiliminde olduğu bildirilir (Aksu, 1998; Eryurt ve Koç, 2009; Akın ve Ersoy, 2012; TÜIKK, 2012a, 2016). İnsanların çevreye karşı biyolojik tepkilerinin zamanla değişmediği düşünüldüğünde (Howel, 1976; Hopa, 2002) eski toplumların yaşam şartlarının ve uyarlanma süreçlerinin demografik yapılarını nasıl etkilediği, geçmişten günümüze nüfus dinamiklerindeki değişimin anlaşılması açısından önemlidir.

Antalya/Alanya Kadiini Mağarası'ndan Geç Kalkolitik/Erken Tunç Çağ1 insan iskeletleri üzerinde yürütülen bu çalışmada, topluluğun, demografik özelliklerinden yola çıkılarak nüfus dinamiklerinin gösterilmesi amaçlanmıştır.

\section{Gereç ve Yöntem Örneklem}

Kadıini Mağarası Antalya ilinin Alanya ilçesinde, ilçenin yaklaşık olarak $15 \mathrm{~km}$ güneydoğusundaki Değirmendere Mahallesi sinırlarında, Kadıpınarı Mevkii olarak bilinen Oba Çayı Vadisi'nde, dik kayalık tepenin yamacındadır. Mağara girișinde daha önceden yapılan araștırmalarda ve sondaj kazısında ele geçen bulgular, buradaki en eski insan izlerini Üst Paleolitik Çağ’a tarihlendirmektedir (Kökten, 1959; Güleç vd., 1998). Kadıini Mağarası'nda daha önceden yapılan araştırmalarda bulunan iki kafatasından oluşan iskelet kalıntılarının (Kökten, 1959) antropolojik incelemeleri ve tarihlendirilmesi Güleç (1994) tarafından gerçekleştirilmiştir. Kafataslarından biri üzerinde uygulanabilen radyo karbon analizle iskeletler MÖ 3. binin başlarına tarihlendirilmiştir (Güleç, 1994). Maden Tetkik ve Arama Genel Müdürlüğü (MTA) tarafindan mağaranın haritası oluşturulurken keşfedilen, sonrasında Süleyman Demirel Üniversitesi Biyospeleoloji Araştırmalar Topluluğu (BAT), Akdeniz Üniversitesi Mağara Araştırmaları Topluluğu (AKÜMAK) ve Anadolu Speleoloji Grubu Derneği (ASPEG) faaliyetlerinde tekrar gündeme gelen
Kadinni’ndeki diğer iskelet kalıntıları, T.C. Kültür ve Turizm Bakanlığı Kültür Varlıkları ve Müzeler Genel Müdürlüğü izni ile Alanya Müzesi Başkanlığı'nda 2017 y1lında disiplinler arası gerçekleştirilen kurtarma çalışmaları ile gün yüzüne çıkarılmıştır. Mağara içerisinde iskeletler anatomik pozisyonları bozulmuş, dağınık ve/ veya karışmış halde olup, bunlar incelenmesi üzere mağara dişına tasnif edilmiştir. Kadiini iskelet topluluğu, beraberindeki arkeolojik buluntular eşliğinde, radyo karbon yöntemiyle yapılan tarihlendirme ile (Güleç, 1994) uyumlu olarak Geç Kalkolitik ve Erken Tunç çağlarına tarihlendirilmiştir (Kadıini Mağarası Sonuç Raporu [KMSR] , 2017).

Kadini Mağarası'nda 2017 yilı kurtarma çalışmalarından ele geçen ve Geç Kalkolitik/Erken Tunç çağlarına tarihlendirilen arkeolojik ve antropolojik buluntular, mağara girişinden 426-820 metreler arasında kalan hat içerisinde, mağara planındaki 22. ve 41 . istasyon noktaları arasında, ana güzergâh ve bağlantılı kollarda; A, B, C, D, E, F, 30A ve G olarak adlandirılan sektörlerde yayılım gösterir (Harita 1). Kadıini Mağarası kurtarma çalışmalarında ulaşılan toplam 2529 adet iskelet kalıntısı anatomik pozisyonları bozulmuş, dağınık ve/veya karışmış durumdadır. Arkeolojik ve antropolojik veriler, mağara sektörlerinin muhtemelen ölülerin gömüldüğü ve/veya bırakıldığ1 alanlar olduğunu gösterir. Mağara sektörlerinin genelinde ele geçen urne tipi seramik kaplara da ölülerin koyulduğu tahmin edilir. Ancak, çoğunun parçalanmış olması ve bütünlüğü kısmen korunmuş olanların ise içerisinde herhangi bir buluntuya rastlanmamas1; kapların muhtemelen mağaraya giren başka insanlar tarafindan tahrip edilmesiyle aç1klanabilir. Ölülerin, doğrudan mağara içerisine bırakıldığı veya yüzeye oldukça yakın gömüldüğü söylenebilir. Bazı kemiklerin üzerinde muhtemelen kemirici hayvanların oluşturduğu diş izlerine rastlandığından (analizleri devam etmektedir) iskeletlerin karışmasında ve açıkta olmasında leş yiyici hayvanların da rolü olduğu düşünülmektedir. Diğer yandan kemiklerin mağara sektörlerindeki sekilerden (düzlükler) ve geniş çukurlardan ele geçirilmesi, muhtemelen ölülerin öncelikle sekilere bırakıldığını daha sonra ise yeni gelenlere yer açmak amaciyla bu çukurlara atıldığını gösterir (KMSR, 2017). İskeletlerin karışmasında, Çatalhöyük Neolitik topluluğu örneğinde olduğu gibi aynı mekânın ölü gömme alanı olarak tekrar tekrarkullanılmasının da etkiliolduğu yüksek ihtimaldedir (Boz ve Hager, 2013). İskeletlerin bir bölümünde gözlemlenen renk değişimlerinin, temasta bulundukları su ve toprağın mineral içeriğinden kaynaklandığ düşünülmekle beraber, bazı kemiklerdeki renk değişimi ve dokusal bozulmaların yanmadan (kremasyon/ölü yakma uygulaması) kaynaklandığı anlaşılmıştır (Mays, 1998) (analizleri devam etmektedir). Ayrıca iskeletlerin 


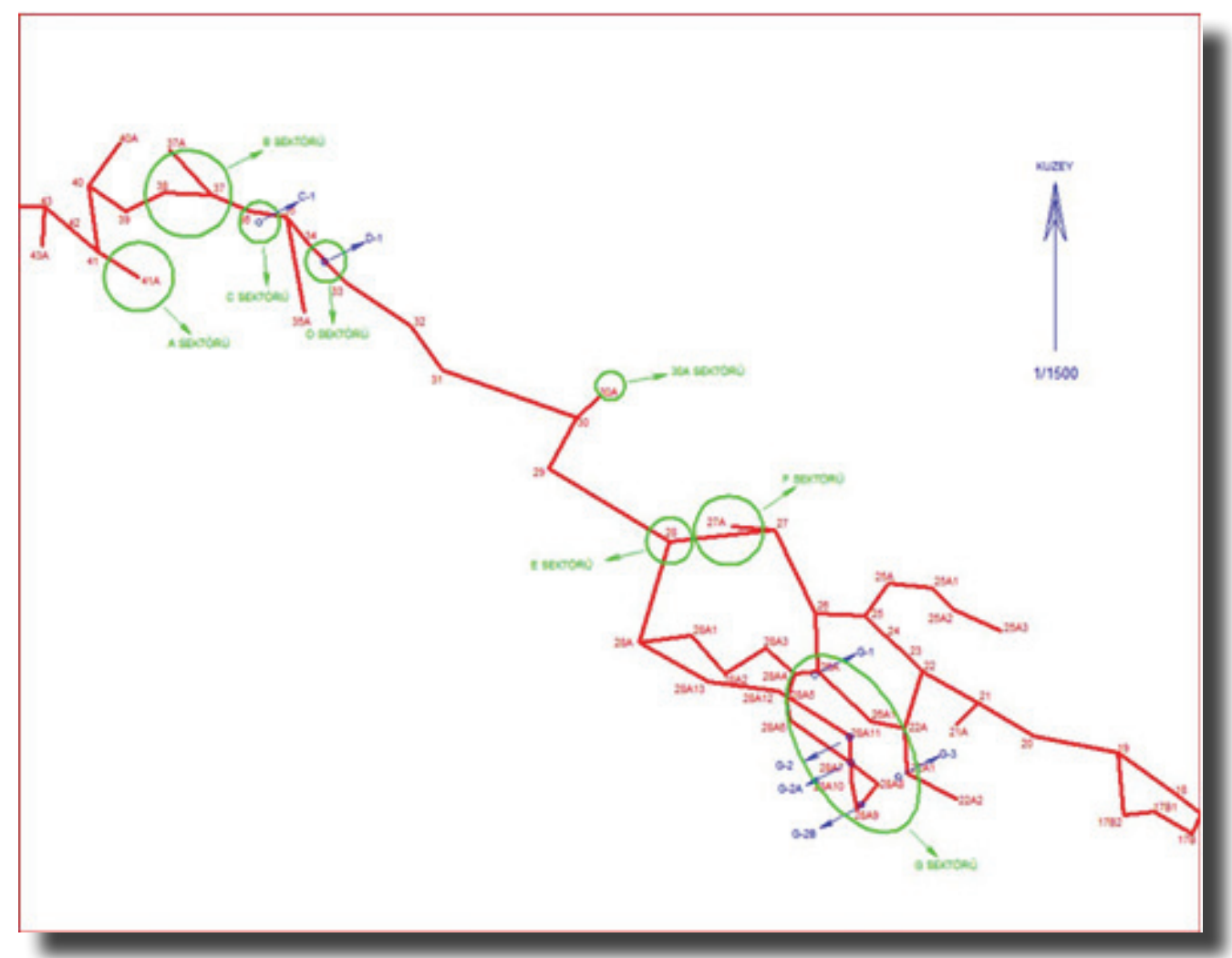

Harita 1. Kadıini Mağarası'nda arkeolojik ve antropolojik buluntuların ele geçirildiği sektörleri gösteren harita

arasında izole hayvan kemikleri bulunmuştur (analizleri devam etmektedir). Eski çağlardan günümüze Ön Asya'da ölü yemeği, anma töreni gibi amaçlarla kurban edilen hayvanların parçalarının mezarların veya ölülerin yanına gömüldüğü göz önüne alındığında (Ökse, 2005; Sang, 2010; Sagona ve Zimansky, 2015; Silibolatlaz Baykara, 2019) Kadini iskeletleri arasında ele geçen hayvan kemiği bulgularının ölü gömme uygulamaları, inanç ve ritüellerle ilişkili olduğu öngörülebilir. Kadiini Mağaras1, Prehistorik Dönem insan kalıntıları içermesi özelliğiyle Anadolu'da (Şenyürek, 1958; Özbek, 2000; Yașar vd., 2012; Becks ve Polat Becks, 2013), Avrupa'da (Cullen, 1995, 1999; Robb vd., 2015) ve Yakın Doğu'da (Ilan ve Rowan, 2015) yer alan bazı mağaralarla benzerlik gösterir.

Kadinini 2017 yılı kurtarma çalışmalarında yüzeyde ve zeminle bağlantısı olmayan iskelet kalıntıları toplanmış; mağara içerisinde ulaşılması tehlikeli olan yerlerdeki iskeletler ve bulunduğu zemine kaynaşmış olanlar yerinde bırakılmıştır. Laboratuvara getirilen iskeletlerdeki kalsit oluşumlar, kemik üzerindeki yoğunluklarına göre seyreltilmiş asetik asit çözeltisi kullanılarak temizlenmiștir.

\section{Minimum Birey Sayısı (MNI)}

Mağarada ulaşılan 2529 adet iskelet kalıntısı, topluluktaki en fazla birey sayısını gösterir. Topluluğu oluşturan minimum birey sayısı ise, iskeletlerin mağara içerisinde bulundukları sektörlere göre tasnif edilerek analiz edilmiştir (Tablo 1). Sektörlerdeki minimum birey sayıları kemiklerin bulundukları sekiler ve çukurlara göre gruplandirılıp farklı yaş ve cinsiyetler dikkate alınarak en fazla tekrar eden kemik sayısı üzerinden belirlenmiştir (Brothwell, 1981; Ubelaker, 1989; White ve Folkens, 2005; Eshed vd., 2008; White vd., 2012). Birey sayısı hesaplanırken birbirlerine yakın sekiler ve çukurlar arasında ele geçen izole kemikler, hesaplamada karışıklık oluşturmaması nedeniyle değerlendirme dışında tutulmuştur; sekiler üzerinde ve çukurlarda yer alan kemikler ayrı gruplar olarak değerlendirilmiştir. Buna göre Kadiini Mağarası iskelet serisinde minimum birey sayıs1 90 olarak belirlenmiştir.

\section{Cinsiyet ve Biyolojik Ölüm Yaşı Tespiti}

Cinsiyet tayini on beş yaşın üzerindeki bireylerde hem topluluğu oluşturan bütün kemiklerin morfolojik yapısının ve belirleyici cinsiyet kıstaslarının (Acsadi ve Nemeskeri, 1970; Workshop of European Anthropologists [WEA], 1980; Brothwell, 1981; Krogman ve İşcan, 1986; Buikstra ve Ubelaker, 1994) hem de metrik ölçülerinin (WEA, 1980; Bass, 1995; Özer ve Sağır, 2003; Spradley ve Jantz, 2011) değerlendirilmesi ile yapılmıştır.

Kadiini iskelet serisinde bebeklerin ve çocukların ölüm yaşlarının belirlenmesinde dişlerin gelişimi, sürüm zamanlar1 (Ubelaker, 1989; Buikstra ve Ubelaker, 1994), ayrica epifizlerin kapanma durumları (Webb ve Suckey, 1985; Ubelaker, 1989; Scheuer ve Black, 2000) esas alınmıştır. Dişlerin ölüm sonrası kayıp olduğu durumlarda uzun kemiklerin diyafiz uzunlukları 
Tablo 1. Kadıini iskelet topluluğunu oluşturan bireylerin mağarada bulundukları sektörlere göre dağılımı

\begin{tabular}{|c|c|c|c|c|c|c|c|c|c|c|c|c|c|c|}
\hline \multirow{2}{*}{ 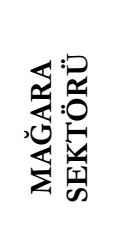 } & \multirow{2}{*}{ 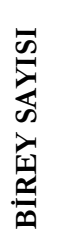 } & \multicolumn{9}{|c|}{ YAŞ } & \multicolumn{3}{|c|}{ CİNSİYET } & \multirow{2}{*}{ 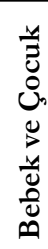 } \\
\hline & & İ & เి & 离 & مُ & $\begin{array}{l}\text { సิ } \\
\text { ஸे }\end{array}$ & 仓ิ & $\begin{array}{l}\text { f } \\
\text { o }\end{array}$ & +ి & $\stackrel{+}{\stackrel{+}{\sim}}$ & 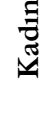 & $\begin{array}{l}\frac{y}{c} \\
\frac{y}{4} \\
\text { cis }\end{array}$ & 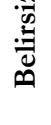 & \\
\hline A & 17 & 2 & 2 & 2 & 3 & 4 & 1 & 1 & & $2^{\mathrm{a}}$ & 5 & 4 & 2 & 6 \\
\hline $\mathrm{B}$ & 47 & 3 & 8 & 7 & 6 & 10 & 4 & 3 & & $6^{\mathrm{b}}$ & 11 & 14 & 4 & 18 \\
\hline $\mathrm{C}$ & 4 & & & 1 & 1 & 1 & & & & $1^{\mathrm{c}}$ & 1 & 2 & & 1 \\
\hline $\mathrm{D}$ & 2 & & & & & & & & & $2^{\mathrm{d}}$ & 1 & 1 & & \\
\hline $\mathrm{F}$ & 8 & 2 & & 2 & 1 & & & & & $3^{e}$ & 2 & 1 & 1 & 4 \\
\hline G & 8 & & 1 & 1 & 1 & & & 1 & & $4^{\mathrm{f}}$ & 2 & 4 & & 2 \\
\hline $30 \mathrm{~A}$ & 4 & 1 & 1 & 1 & & & & & & 1 & & & 1 & 3 \\
\hline Toplam & 90 & 8 & 12 & 14 & 12 & 15 & 5 & 5 & 0 & 19 & 22 & 26 & 8 & 34 \\
\hline
\end{tabular}

a: 2 birey 20+; b: 4 birey 20+; c: 1 birey 20+; d: 2 birey 20+; e: 2 birey 20+; f: 1 birey 20+, 1 birey ise 35+ yaş olarak belirlenmiştir

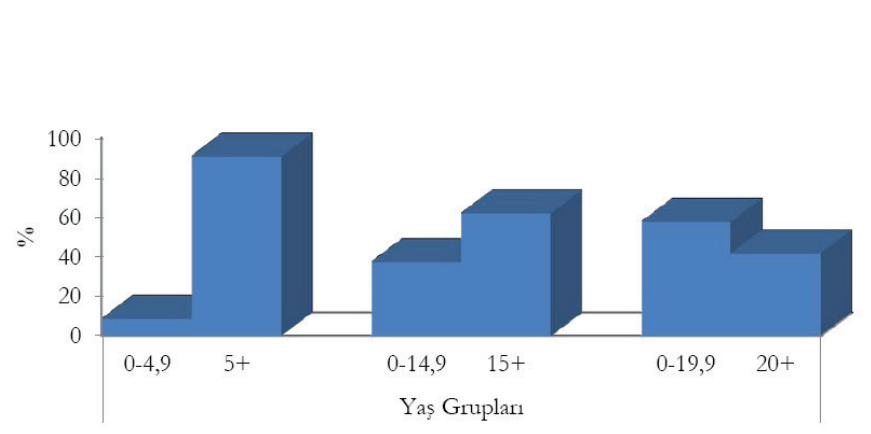

Grafik 1. Kadiini topluluğu genelinde 0-5 yaş; $0-15$ yaş; $0-20$ yaş grubu ölüm oranları

(Maresh, 1970; Fazekas ve Kosa, 1978), clavicula genişliği (Scheuer ve Black, 2000) gibi mevcut vücut kemiklerinin büyüme oranlarına başvurularak biyolojik ölüm yaşı belirlenmiştir. Erişkinlerde biyolojik ölüm yaşı epifizlerin kaynaşma aşamaları (Webb ve Suckey, 1985; Ubelaker, 1989; Scheuer ve Black, 2000), kalça kemiğinde symphysis pubis (Brooks ve Suchey, 1990) ve auricular yüzey (Lovejoy vd., 1985) morfolojileri, kafatası suturlarının kapanma izleri (Meindl ve Lovejoy, 1985), dişlerin yıpranma durumu (Brothwell, 1981) gibi ölçütlerle saptanmıştır (WEA, 1980; Krogman ve İşcan, 1986; Buikstra ve Ubelaker, 1994; White vd., 2012).

\section{Demografik Yöntemler}

Kadiini iskelet topluluğunda 15-29,9 yaş arası genç erişkin, 30-44,9 yaş arası orta erişkin ve 45 yaş üzeri bireyler ileri erişkin olarak gruplandırllırken (Büyükkarakaya, 2017), fetus, yeni doğan ve 14,9 yaşa kadar olan bireyler, yaşlandırmada oluşabilen hata payı göz önünde bulundurularak bebek ve çocuklar olarak

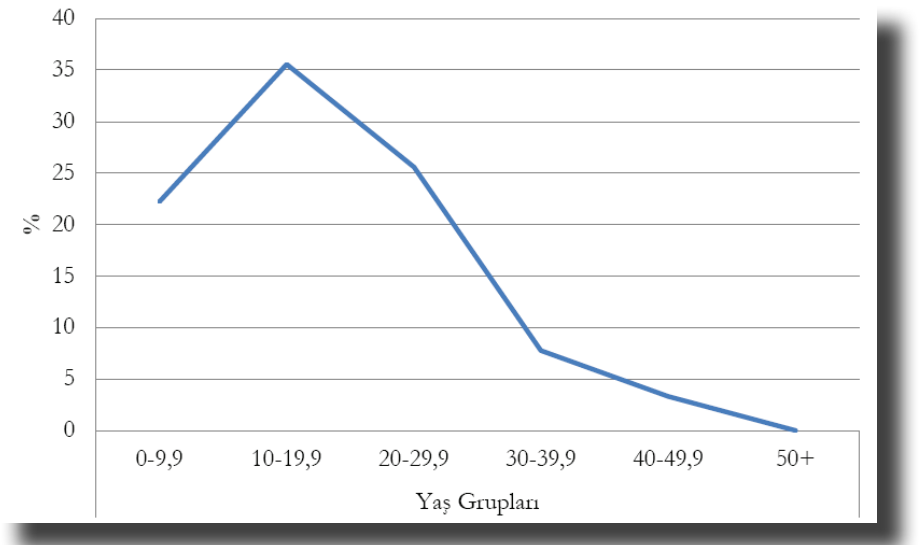

Grafik 2. Kadiini topluluğunun ölüm eğrisi (dx)

bir arada değerlendirilmiştir (Tablo 2). Topluluğun demografik verileri onarlı yaş aralıklarına göre oluşturulan yaşam tabloları̈̈zerinden değerlendirilmiştir (Ubelaker, 1989). On beş yaşın üzerinde olduğu tespit edilen ancak yaş grubu kesin olarak belirlenemeyen bireyler, gözlenen değerlerin gerçek ölüm oranlarını temsil ettiği varsayılarak uygun yaş gruplarına oransal olarak dağıtılmıştır (Johansson ve Horowitz, 1986; Eshed vd., 2008; Büyükkarakaya, 2017). Kadiini topluluğu demografik özelliklerinin karşılaştırılması amaciyla bazı Anadolu Prehistorik toplumlarının birey sayıları beşerli yaş gruplarına göre oluşturulan yaşam tabloları verilerinden onarlı yaş gruplarına kümelenerek yeniden hesaplanmıştır.

\section{Bulgular}

Kadini Mağarası'ndan tanımlanan 90 bireyin \%37,78'ini $(\mathrm{N}=34)$ bebek ve çocuklar oluşturur (Grafik 1). On beş yaş üstü bireyler arasında en yüksek oran \%30,00 ile genç erişkinlik yaş grubundadır (Tablo 2). 
Y1lmaz Usta|Antropoloji 38 (2019), 65-78

Tablo 2. Kadıini insanlarının yaş ve cinsiyete göre dağılımı

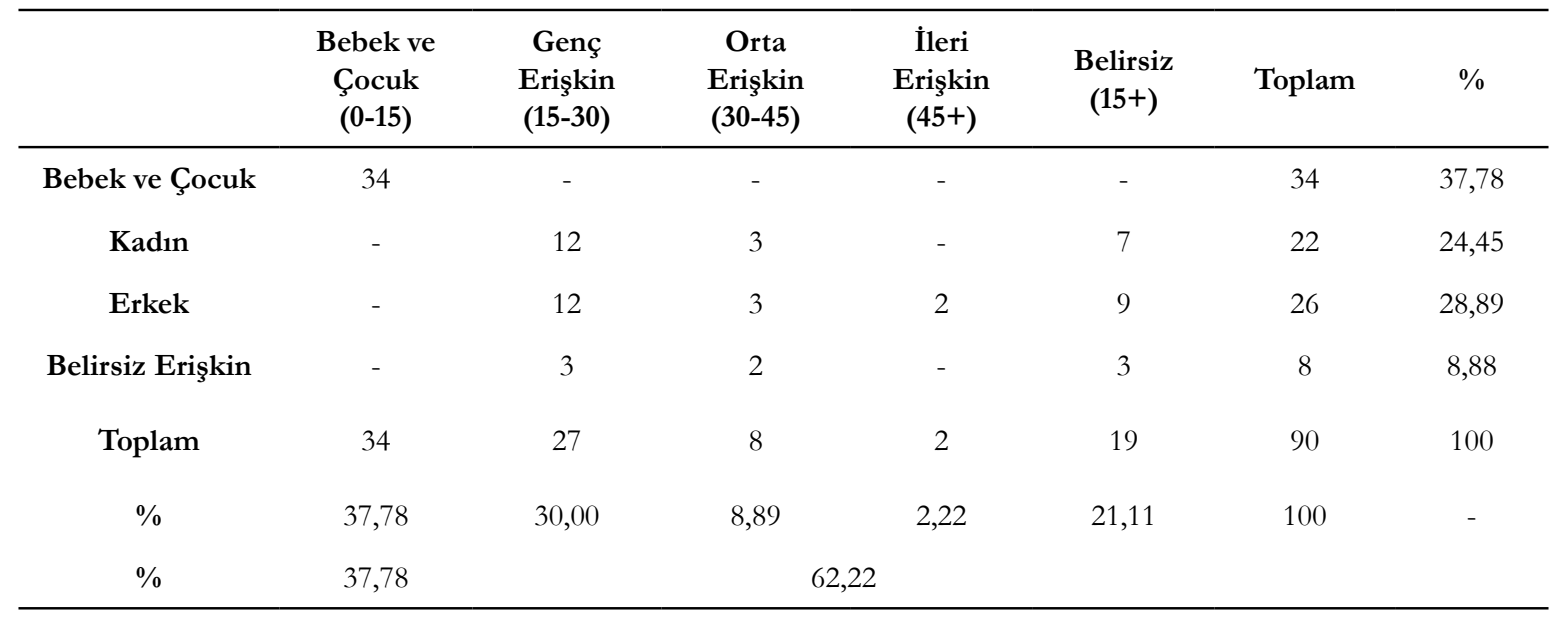

Demografik özellikler yaşam tabloları üzerinden incelendiğinde (Tablo 3) toplulukta 0-9 yaş grubunun ölüm oranı \%22,22'dir (Grafik 1) ve bu yaş grubunda (doğumdaki) yaşam beklentisi 19,56 yıldır. Toplulukta 10-19 yaş grubunun en yüksek ölüm oranına $(\% 35,56)$ sahip olduğu görülür (Grafik 2). Bu yaş aralığındaki yüksek ölümlülük dikkate alındığında 20 yaşın altındaki bireyler topluluğun $\% 57,58$ 'i olmak üzere yüksek bir oranı oluşturur (Grafik 1). Toplulukta 20 yaşına ulaşmış bireylerin hayatta kalma şansı (Ix) \% 77,78'dir. Diğer yandan 10-19 yaş grubundan itibaren birey sayısının azaldığı ve 50 yaşın üzerinde yaşayan bireyin bulunmadığ1 görülür. Kadinililerin yaşam beklentisi $\left(\mathrm{e}^{0} \mathrm{x}\right)$, doğumda 19,56 y1l iken ilerleyen yaşlarda azalarak 40-49 yaş grubunda 5 yila kadar geriler (Tablo 3).

Toplulukta ölüm yaşı ortalaması (15+ yaş) 25,9 y1ldir $(\mathrm{N}=37)$. Cinsiyeti belirlenebilen bireylerin 22'si kadın, 26's1 erkektir ve kadın erkek oranı $(0,84)$ essit değildir. Erkeklerin ortalama yaşam uzunluğu $(26,8$ yıl; $\mathrm{N}=17)$ kadınlarınkinden (24,5 yıl; $\mathrm{N}=15)$ yaklaşık 2 yıl daha yüksektir.

\section{Tartışma ve Sonuç}

Nüfus artışı, demografik yönelimin yorumlanmasında önemli bir konudur. Büyüyen bir popülasyonun ortalama ölüm yaşı ve yaşam beklentisi daha düşük; küçülen bir popülasyonun ise daha yüksektir (Eshed vd., 2008). Kadini toplumunun ortalama ömür uzunluğunun (25,9 y1l), gerek Anadolu'daki bazı Kalkolitik ve Tunç Çağı toplulukları arasında değerlendirildiğinde (Angel, 1970; 1986; Wittwer-Backofen, 1988; Aç1kkol, 2000; Sevim vd., 2005; Özdemir, 2011; Sağır vd., 2011; Açıkkol Yıldırım, 2013; Açıkkol Yıldırım vd., 2014; Gökdemir, 2014) (Grafik 4) gerekse Anadolu genelinde tarihsel zamanlara göre incelendiğinde (Koca Özer vd., 2008) hem Kalkolitik Çağ (32,5 y1) hem de Tunç Çă̆ı (36,0 yıl) toplumlarının ortalamasından düşük olduğu görülür. Ortalama yaşam süresi Truva TÇ (Angel, 1986), Oylumhöyük ETÇ (Gökdemir, 2014) ve Seyitömer

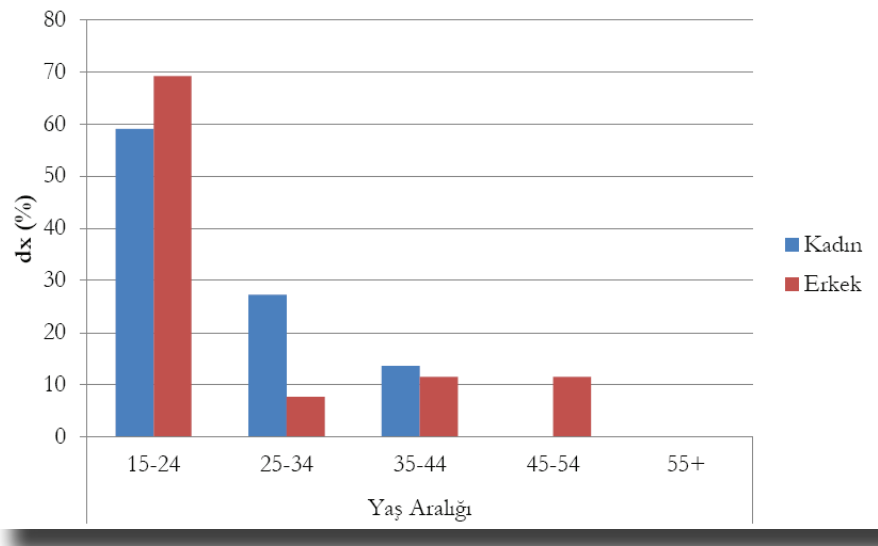

Grafik 3. Kadıini topluluğunda kadın ve erkeklerin ölüm yaşlarına göre dağılımı

OTÇ (Özdemir, 2011) toplumlarının değerlerine yakındır. Ortalama yaşam süresi Alanya özelinde değerlendirildiğinde, Kalkolitik/ETÇ’den (Kadiini topluluğu erişkinlerinin ortalama yaşam uzunluğu 25,9 yıl; ilgili çalışma) Bizans Dönemi'ne (Alanya Kalesi topluluğu erişkinlerin ortalama yaşam uzunluğu 34,0 yll; Üstündağ ve Demirel, 2008) kadar geçen sürede arttığ1 anlaşılmaktadır. Kadıini toplumunda 10 yaşına ulaşmış bireylerin hayatta kalma şansı (Ix: \%77,78) Anadolu'daki bazı Tunç Çağ1 toplumlarının (Açıkkol, 2000; Özdemir, 2011; Açıkkol Yıldırım, 2013; Gökdemir, 2014) ortalamasının üzerinde iken, bu yaş aralığından itibaren hızla azalarak 20 yaşına ulaşmış bireylerin hayatta kalma şans1 (Ix: \%42,22) Oylumhöyük ETÇ (Gökdemir, 2014) ve OTÇ (Açıkkol, 2013) toplumlarına benzer (Grafik 5). Bu durum topluluk içerisinde 10-19 yaş aralığında ölüm oranının yüksek olmasıyla ilişkilendirilebilir. Kadiinililerin doğumdaki yaşam beklentisinin $\left(\mathrm{e}^{0} \mathrm{x}\right.$ : 19,56 y1l), Grafik 7'den incelendiğinde Anadolu bazı tarihöncesi toplumları arasında (Açıkkol, 2000; Özdemir, 2011; Açıkkol Yıldırım, 2013; Gökdemir, 2014) ortalama bir oranda olduğu gözlemlenir. Eski toplumlar arasında doğumdaki yaşam beklentisi, Türkiye'nin günümüz nüfus verileriyle karşılaştırıldığında oldukça düşük değerlerdedir (Koca Özer vd., 2008). TÜİK 2016 
Y1lmaz Usta|Antropoloji 38 (2019), 65-78

Tablo 3. Kadıini topluluğunun 10'arlı yaş gruplarına göre oluşturulan yaşam tablosu

\begin{tabular}{|c|c|c|c|c|c|c|c|}
\hline Yaş Grubu & $\begin{array}{l}\text { Ölen Birey } \\
\text { Say1sı }\end{array}$ & $\begin{array}{l}\text { Ölen Birey } \\
\text { Yüzdesi }\end{array}$ & $\begin{array}{c}\text { Hayatta } \\
\text { Kalma Şansı }\end{array}$ & $\begin{array}{c}\text { Ölüm } \\
\text { Olasılığ1 }\end{array}$ & $\begin{array}{c}\text { Yaşanan } \\
\text { Birey-Yıllar } \\
\text { Toplamı }\end{array}$ & $\begin{array}{c}\text { Yaşanan } \\
\text { Birey-Yıllar } \\
\text { Toplamı }\end{array}$ & $\begin{array}{c}\text { Yaşam } \\
\text { Beklentisi }\end{array}$ \\
\hline $\mathbf{X}$ & Dx & $d(x)$ & $\mathbf{I x}$ & Qx & $\mathbf{L x}$ & $\mathbf{T} \mathbf{x}$ & $e^{0} x$ \\
\hline $0-9$ & 20 & 22,22 & 100 & 0,2222 & 888,889 & 1955,556 & 19,56 \\
\hline $10-19$ & 32 & 35,56 & 77,78 & 0,4571 & 600,000 & 1066,667 & 13,71 \\
\hline $20-29$ & 23 & 25,56 & 42,22 & 0,6053 & 294,444 & 466,667 & 11,05 \\
\hline $30-39$ & 7 & 7,78 & 16,67 & 0,4667 & 127,778 & 172,222 & 10,33 \\
\hline $40-49$ & 8 & 8,89 & 8,89 & 1,0000 & 44,444 & 44,444 & 5,00 \\
\hline $50+$ & 0 & 0 & 0 & 0 & 0 & 0 & 0 \\
\hline Toplam & 90 & 100,00 & & & & & \\
\hline
\end{tabular}

Tablo 4. Kadıini kadın bireylerinin 10'arlı yaş gruplarına göre oluşturulan yaşam tablosu

\begin{tabular}{|c|c|c|c|c|c|c|c|}
\hline Yaş Grubu & $\begin{array}{l}\text { Ölen Birey } \\
\text { Say1s1 }\end{array}$ & $\begin{array}{l}\text { Ölen Birey } \\
\text { Yüzdesi }\end{array}$ & $\begin{array}{c}\text { Hayatta } \\
\text { Kalma Şansı }\end{array}$ & $\begin{array}{l}\text { Ölüm } \\
\text { Olasılığ́1 }\end{array}$ & $\begin{array}{c}\text { Yaşanan } \\
\text { Birey-Yıllar } \\
\text { Toplamı }\end{array}$ & $\begin{array}{c}\text { Yaşanan } \\
\text { Birey-Yıllar } \\
\text { Toplamı }\end{array}$ & $\begin{array}{c}\text { Yaşam } \\
\text { Beklentisi }\end{array}$ \\
\hline $\mathbf{X}$ & Dx & $d(x)$ & $\mathbf{I x}$ & Qx & $\mathbf{L x}$ & $\mathbf{T x}$ & $e^{0} x$ \\
\hline $15-24$ & 13 & 59,09 & 100 & 0,5909 & 704,545 & 1045,455 & 10,45 \\
\hline $25-34$ & 6 & 27,27 & 40,91 & 0,6667 & 272,727 & 340,909 & 8,33 \\
\hline $35-44$ & 3 & 13,64 & 13,64 & 1,0000 & 68,182 & 68,182 & 5,00 \\
\hline $45-54$ & 0 & 0 & 0 & 0 & 0 & 0 & 0 \\
\hline $55+$ & 0 & 0 & 0 & 0 & 0 & 0 & 0 \\
\hline Toplam & 22 & 100,00 & & & & & \\
\hline
\end{tabular}

Tablo 5. Kadıini erkek bireylerinin 10'arlı yaş gruplarına göre oluşturulan yaşam tablosu

\begin{tabular}{|c|c|c|c|c|c|c|c|}
\hline Yaş Grubu & $\begin{array}{l}\text { Ölen Birey } \\
\text { Sayısı }\end{array}$ & $\begin{array}{l}\text { Ölen Birey } \\
\text { Yüzdesi }\end{array}$ & $\begin{array}{c}\text { Hayatta } \\
\text { Kalma Şansı }\end{array}$ & $\begin{array}{l}\text { Ölüm } \\
\text { Olasılığ1 }\end{array}$ & $\begin{array}{c}\text { Yaşanan } \\
\text { Birey-Y1lar } \\
\text { Toplamı }\end{array}$ & $\begin{array}{c}\text { Yaşanan } \\
\text { Birey-Yıllar } \\
\text { Toplamı }\end{array}$ & $\begin{array}{c}\text { Yaşam } \\
\text { Beklentisi }\end{array}$ \\
\hline $\mathbf{X}$ & Dx & $d(x)$ & $\mathbf{I x}$ & Qx & $\mathbf{L x}$ & $\mathbf{T x}$ & $\mathbf{e}^{0} \mathbf{x}$ \\
\hline $15-24$ & 18 & 69,23 & 100 & 0,6923 & 653,846 & 1153,846 & 11,54 \\
\hline $25-34$ & 2 & 7,69 & 30,77 & 0,2500 & 269,231 & 500,000 & 16,25 \\
\hline $35-44$ & 3 & 11,54 & 23,08 & 0,5000 & 173,077 & 230,769 & 10,00 \\
\hline $45-54$ & 3 & 11,54 & 11,54 & 1,0000 & 57,692 & 57,692 & 5,00 \\
\hline $55+$ & 0 & 0 & 0 & 0 & 0 & 0 & 0 \\
\hline Toplam & 26 & 100,00 & & & & & \\
\hline
\end{tabular}




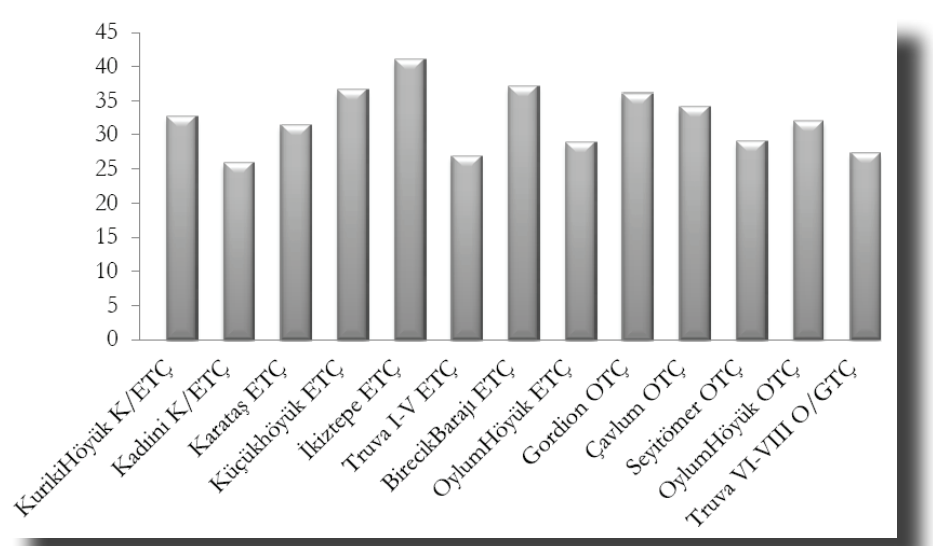

Grafik 4. Bazı Kalkolitik ve Tunç Çă̆ı Anadolu Toplumları arasında ortalama ömür süreleri.

K: Kalkolitik; TÇ: Tunç Çağı; ETÇ: Erken Tunç Çă̆ı;

OTÇ: Orta Tunç Çă̆ı; GTÇ: Genç Tunç Çă̆ı

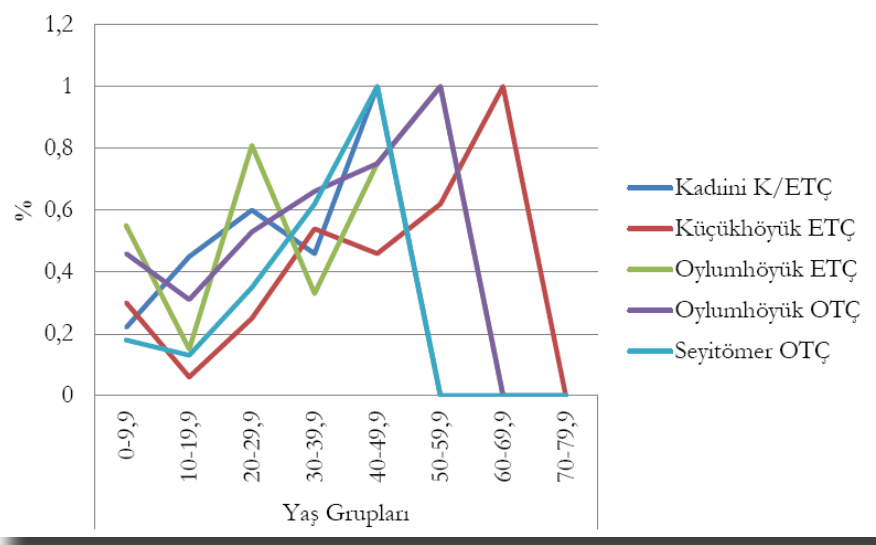

Grafik 6. Bazı Anadolu Tunç Çağı toplumlarında ölüm olasılıkları (qx)

yılı araştırmalarında Türkiye için 2000 y1lında doğuşta beklenen yaşam süresinin 71 yıl olduğu, 2023 yılında bu sürenin 77,9 yıla yükseleceği, ilgili y1llar arasında $0-15$ yaş nüfusun azalırken 15 yaş üstü nüfusun artacağ 1 ve bu veriler doğrultusunda ülkenin durağanlaşan bir nüfusa sahip olacağı bildirilmiştir (TÜİK, 2016). Günümüz verileri göz önünde bulundurulduğunda Kadiini topluluğunun ortalama yaşam süresi, hayatta kalma şansı ve yaşam beklentisi bulgularından diğer eski toplumlar gibi genç ve büyüyen bir nüfusa sahip olduğu anlaşılmaktadır.

Kadıini Kalkolitik/Erken Tunç Çağ1 topluluğunda ilk beş yaş içerisindeki ölümlülük oranının $(\% 8,9)$ görece düşük olması (Grafik 1), diğer birçok eski toplulukta da olduğu gibi bebek iskeletlerinin narin yapılarından dolayı tahrip olmaları ve/veya bazı kültürlerde ayrı mezarlık alanlara gömülebilmeleriyle açıklanabilir (Özbek, 1985; Açıkkol, 2000; Paine ve Boldsen, 2002; Sevim vd., 2002; Açıkkol vd., 2004; Özbek ve Erdal, 2006; Uysal, 2006; Alpaslan-Roodenberg, 2008a; Üstündağ ve Demirel, 2008; Sağır vd., 2011; Yiğit vd., 2011; Demirel, 2013; Erdal, 2017).

Anadolu'daki Kalkolitik-Tunç Çağı topluluklarında 0-15 yaş arası yaşamını yitiren bireylerin oranı $\% 30-\% 66$

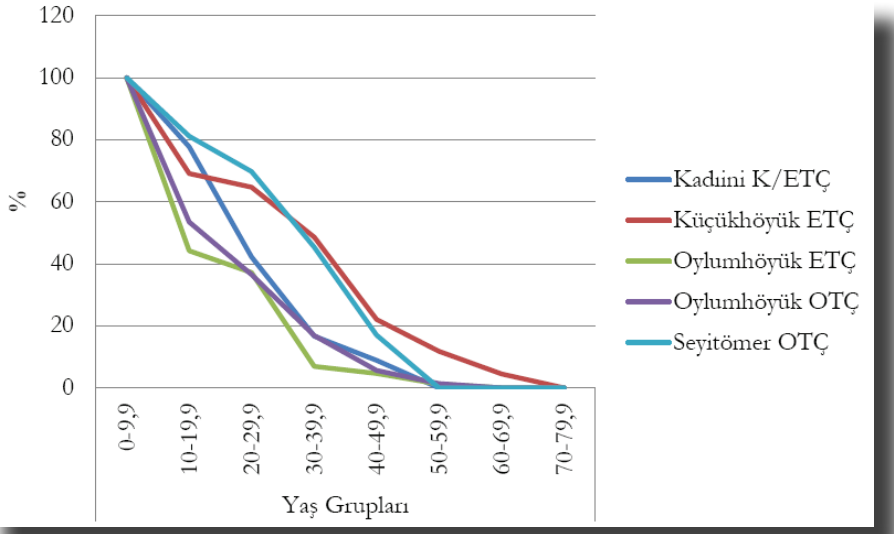

Grafik 5. Bazı Anadolu Tunç Çağı toplumlarında yaşam eğrileri (Ix)

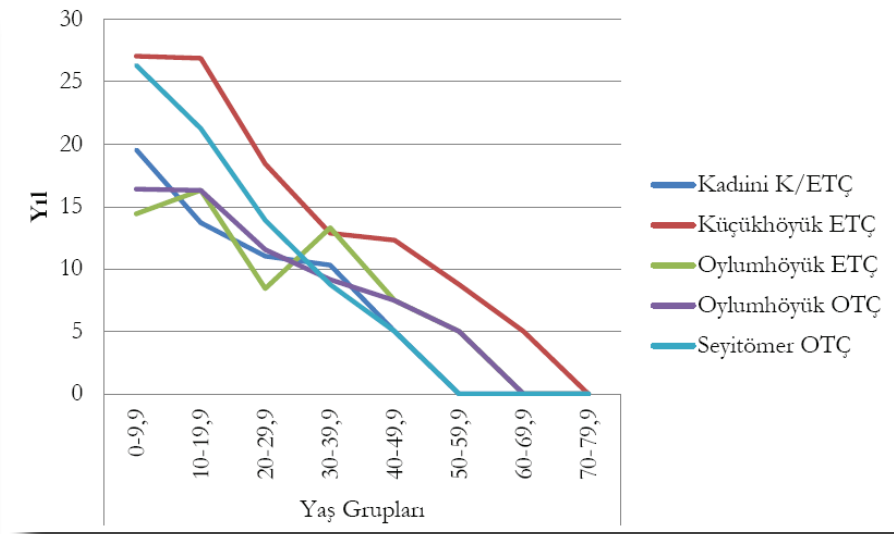

Grafik 7. Bazı Anadolu Tunç Çağı toplumlarında yaşam beklentisi eğrileri $\left(\mathrm{e}^{0} \mathrm{x}\right)$

arasinda (Angel, 1972; Özbek, 1985; Wittwer-Backofen, 1988; Açıkkol, 2000; Sevim vd., 2005; Atamtürk ve Duyar, 2010; Erdal, 2012; Açıkkol Yıldırım, 2013; Gökdemir, 2014; Koruyucu, 2019); 20 yaşına ulaşmadan ölenlerin oranı ise \%35-\%63 arasında değişmektedir (Atamtürk ve Duyar, 2010; Açıkkol Yıldırım, 2013; Açıkkol Yıldırım vd., 2014). Kadıini'nde 0-5 yaş (\%8,89), 0-15 yaş arası ölüm oranları $(\% 37,78)$ her ne kadar düşük görünse de 20 yaşına ulaşmadan hayatını kaybeden bireylerin oran1 (\%57,78) (Grafik 1) Anadolu'daki çağdaş1 birçok toplumdan yüksektir. Anadolu bazı Tunç Çağ1 toplumları arasında değerlendirildiğinde (Açıkol, 2000; Özdemir, 2011; Açıkkol Yıldırım, 2013; Gökdemir, 2014) Kadinini insanlarının 10-19 yaş grubunda ölüm olasılığının da yüksek olduğu gözlemlenir (Grafik 6).

Eski topluluklar üzerinde yapılan araştırmalarda, Neolitik Çağ'dan itibaren yerleşik hayata geçişle birlikte yeni yaşam biçimine uyarlanmayla doğurganlığın ve nüfusun artmasina paralel olarak özellikle bebek, çocuk ve ergen yaştaki ölümlerin arttığ 1 bildirilmiştir (Acsadi ve Nemeskeri, 1970; Angel, 1972; 1975; 1984; Özbek, 1998; 2004; Paine ve Boldsen, 2002; AlpaslanRoodenberg, 2008b; Koca Özer vd., 2008; Erdal, 2009; 2013; Larsen vd., 2015; Knüselvd., 2016; Büyükkarakaya, 
2017). Bebek ve çocukların ölüm oranı, eski Anadolu toplumlarında Neolitik Çağ'dan itibaren hemen her dönem topluluk içerisinde oldukça yüksek olsa da (Koca Özer vd., 2008; Akın ve Ersoy, 2012; TÜİK, 2012a, 2016) en yüksek değere ilk olarak Tunç Çă̆ı'nda ulaşır. $\mathrm{Bu}$ çağdan itibaren bebek ve çocukların ölüm oranı azalma göstererek Ortaçağ'da tekrar yüksek değere çıkar (Koca Özer vd., 2008). Avrupa eski toplumlarında çocuk ölümlülüğü incelendiğinde de oranın Tunç ve Demir çağlarında oldukça arttığı; bu çağlarda özellikle 5-18 yaş grubu çocukların ölüm oranının; nüfus boyutu ve yoğunluğunun artmasiyla birlikte ilerleyen zamanlarda ise 2-5 yaş grubu çocukların ölüm oranının yüksek olduğu görülmüştür. Araştırmalarda nüfusun büyümesi neticesinde Avrupa toplumlarının Asya ve Akdeniz toplumları ile bağlantılarının arttı̆̆1, toplumlar arası temasların başlıca salgın hastalıkların oluşmasında, yayılmasında önemli etkiler oluşturduğu ve bu nedenlerle özellikle Ortaçağ'da erken çocukluk dönemi ölümlerinde artışın ivme kazandığı belirtilmiştir (Paine ve Boldsen, 2002). Günümüz (Caldwell, 2001; Akın ve Ersoy, 2012; TÜIKK, 2012a, 2016) ve eski Anadolu toplumlarını araştıran çalışmalarda (Güleç, 1988; 1989; Arman, 1991; Sevim, 1993; 2006; Erdal, Y.S. 1993; 2000; 2011; Uysal, 1995; Özer vd., 1999; Açıkkol, 2000; Gözlük-Kırmızığlu, 2005; Özbek ve Erdal, 2006; Koca-Özer vd., 2008; Güleç ve Özer, 2009; Çırak ve Çırak, 2010; Erdal ve Özbek, 2010; AçıkkolYildırım, 2013; Alkan ve Erkman, 2013; Demirel, 2013; Gökdemir, 2014; Başoğlu vd., 2015; Erdal, Ö.D. 2017) bebek, çocuk ve ergenlerin ölümlerine yol açan etmenlerin toplumların yaşam şartları ve biyokültürel uyarlanmalarıyla doğrudan ilişkili olduğu vurgulanır. Toplumların uyarlanma sürecini yönlendiren çevresel özellikler, geçim ekonomisi, beslenme rejimleri, temizlik alışkanlıkları, kültürel davranış biçimleri gibi birbiriyle bağlantılı birçok etmen doğrudan veya dolaylı olarak bağışıklık sistemleri henüz tam olarak gelişmemiş olan bebek, çocuk ve ergenlerin yaşamlarına yansır (Özcebe, 2006; Konuk-Şener ve Ocakç1, 2014). Demografik yap1 ve sağlıkla ilgili araştırmaların genelinde düşük doğum ve ölüm hızının refah düzeyi yüksek toplumların özelliği olduğu, bebek, çocuk ve ergen ölümlerinin, toplumların sağl1k durumu ve sosyal refahındaki iyileşmeye paralel olarak azalma eğiliminde olduğu bildirilir (Greulich, 1957; Tezcan, 1985; Caldwel, 2001; Okyay vd., 2006; Eryurt ve Koç, 2009; Akın ve Ersoy, 2012; TÜİK, 2012a, 2016). Mevcut verilerin topluluğun tamamını temsil ettiği varsayıldığında Kadıini topluluğunda da nüfusun yaklaşık yarısının 20 yaşın altında ölmesinde $(\% 57,78)$ ve 45 yaş üzerine ulaşabilmiş bireylerin çok az sayıda olmasında yaşam şartlarının önemli etkisi olduğu düşünülebilir.

Kadiini insanlarının yaşam biçimleri ve ekonomilerine ilișkin arkeolojik veriler yetersiz olsa da araştırmalarda Anadolu'da Neolitik Çağ'dan Erken Tunç Çağ1 II'ye kadar yerleşim yerlerinin büyüyerek arttığı ve Kalkolitik Çağ’’n sonunda başlayan kentleşmeyle beraber Erken Tunç Çağı'nda toplumların karmaşık bir yap1 kazandığı bildirilir (Abay, 2011; Massa, 2014). Erken Tunç Çağı; geniş ticaret ağlarının oluşmaya başlamasıyla beraber (Steadman, 2011; Massa, 2014; Sagona ve Zimansky, 2015), yerleşim yerlerinde yıkımların ve belirgin iklimsel değişimlerin görüldüğü ve bunlara bağlı olarak göçlerin ve sosyal yapıda yeniden örgütlenmelerin gerçekleştiği bir evredir. Bu dönemde muhtemelen hammadde ve doğal kaynak arayışı ile beraber gruplar arası temasların da artmasına bağl1 olarak ortaya çıkan rekabette tehlikelerden korunmak amaciyla yerleşim yerleri geniş savunma duvarlar1 ile çevrelenmiştir (Massa, 2014; Sagona ve Zimansky, 2015). Öyle ki Erken Tunç Çağı Anadolu topluluklarının bazılarında örgütlü şiddetin de izleri gözlenebilmektedir (Erdal, 2012; Erdal ve Erdal, 2012). Bu olası nedenlerden dolayı özellikle Erken Tunç Çağı I ve II'de Anadolu'da hayvancillk geçim ekonomisi süren yarı göçebe toplulukların tekrar çoğaldığına ve nüfusun kırsal alanlara kaydığına dikkat çekilir. Bu dönemde ani iklim değişikliğiyle ortaya çıkan kuraklığın vadi sistemi boyunca hem höyük yerleşimlerinin sayısının hem de genel nüfusun azalmasina yol açtı̆̆ı, buna bağlı olarak küçük yerleşmelerin arttığ1 ve beraberinde kırsal hayvancılık ve yerel grupların hareketliliğinin yeniden yaygınlaştı̆̆1 bildirilir (Wossink 2009; Massa, 2014; Sagona ve Zimansky, 2015). Anadolu Erken Tunç Çağı'nda yaşanan bu gelişmelerin Kadinililerin demografik yapısının şekillenmesinde muhtemelen etkili olmasiyla beraber, iskeletlerin patolojik analizleri tamamlandiğında topluluğun nüfus özelliklerine etki eden olas1 etmenlerin daha iyi anlaşılacağ tahmin edilmektedir.

Kadini topluluğunda cinsiyetler arasindaki demografik farklılıklar yaşam tabloları üzerinden incelendiğinde 15-24 yaş grubu her iki cinsiyet için de ölüm riskinin en yüksek olduğu dönem olarak değerlendirilebilir. Ancak bu yaş grubundaki yaşam beklentisi $\left(e^{0} x\right)$ kadınlarda $(10,45 \mathrm{y} 1)$ erkeklerden $(11,54$ yıl) yaklaşık 1 yıl daha düşüktür. Kadınlarda 35 yaşa kadar hayatta kalma şansı (Ix) daha yüksek olsa da, erkeklerin 45 yaş üzerinde hayatta kalma şansı ve yaşam beklentisi devam ederken kadınlarınki sonlanmaktadır. TÜIKK 2013-2023 verileri incelendiğinde günümüzde kadınların doğuşta beklenen yaşam süresinin erkeklerinkinden daha fazla olduğu görülür ve bu değişime evlilik yaşının artması, doğum sıklığının azalması gibi kadınların lehine düzelen yaşam standartları gösterilir (TÜİK, 2012b). Diğer yandan Doğu Akdeniz (Angel, 1972; Eshed vd., 2008) ve Anadolu Prehistorik toplumları (Açıkkol, 
2000; Açıkkol Yıldırım, 2013; Açıkkol Yıldırım vd., 2014; Başoğlu ve Şener, 2015; Büyükkarakaya, 2017) üzerinde yapılan araştırmalarda ise günümüzden farklı olarak kadınların ortalama ölüm yaşının erkeklerden daha düşük olması ve özellikle ergenlik, genç erişkinlik yaşlarında yüksek ölüm oranına sahip olmaları; gebelik, doğum yapma, emzirme gibi etmenlerin onlar için yüksek ölüm riski oluşturmasıyla ilişkilendirilmiştir. Yaşam tablosu bulgularıyla birlikte kadınların ortalama yaşam süresinin (24,5 yıl) erkeklerden (26,8 yıl) yaklaşık 2 yıl daha düşük olduğu göz önüne alındığında Kadiini'nde de bazı Doğu Akdeniz (Angel, 1972; Eshed vd., 2008) ve Anadolu Prehistorik toplumlarındaki (Açıkkol, 2000; Açıkkol Yıldırım, 2013; Açıkkol Yıldırım vd., 2014; Başoğlu ve Şener, 2015; Büyükkarakaya, 2017) benzer etmenler doğrultusunda kadınların, fizyolojik ve biyolojik olarak daha fazla yıprandiklarından, zayıf düştüklerinden ölüm risklerinin erkeklerden daha yüksek olduğu düşünülebilir.

Cinsiyeti belirlenebilen bireylerin 22'si kadın, 26's1 erkektir. Kadiini topluluğundaki kadın erkek oranı $(0,84)$ eşit değildir. Kadın erkek oranı Anadolu Tunç Çağ1 toplumlarından Resuloğlu'nda (ETÇ) 1,25 (Atamtürk ve Duyar, 2010), Oylumhöyük'te (OTÇ) 1,16'dır (Açıkkol Yıldırım, 2013). Anadolu eski toplumları üzerinde yürütülen araştırmalar genelinde kadın/ erkek oranının eşit olamamasında mevcut iskeletlerin topluluğun tamamını temsil etmemesinin, yani topluluğa ait iskeletlerin tamamına ulaşılamamış olmasının etkili olduğu belirtilmiştir (Atamtürk ve Duyar, 2010; Açıkkol Yıldırım, 2013; Açıkkol Yıldırım vd., 2014; Duyar vd., 2017). Bunun yanı sıra farklı araştırmalarda eski toplumlardaki kadın erkek oranı eşitsizliğinin farklı ölü gömme uygulamalarından kaynaklanmış olma ihtimali de değerlendirilmiştir (Eshed vd., 2008). Anadolu'daki hem tarihi hem de tarih öncesi bazi eski toplumlarda çocuklara ve/veya kadınlara veya yüksek statülü kişilere farklı ölü gömme uygulamaları yapıldığı bilinir (Erdal vd., 2003; Uysal, 2006; AlpaslanRoodenberg, 2008a; Sagona ve Zimansky, 2015). Avrupa ve Akdeniz çevresi ETÇ toplumlarıly ilgili araştırmalarda bu dönemde sayıca fazla insan gerektiren ekonomik ve sosyal faaliyetlerin ilk zirveye ulaştı̆̆1, bölgesel ve bölgeler arası kültürel temasların ve sosyal tabakalaşmanın ortaya çıkmaya başladığı (Carozza vd., 2006; Faure, 2012; Müller, 2015; Capuzzo vd., 2018), dolayısıyla birbirlerine çok yakın topluluklarda bile ölü gömme uygulamalarının değişkenlik gösterdiği ve farklı cinsiyet, yaş grupları ve sosyal sinıflar arasında farklı olabildiği bildirilmiştir (Müller, 2015; Sagona ve Zimansky, 2015). Kadiini topluluğu için ölü gömme uygulamalarının bireyler arasında farklı olabileceğine ilişkin yeterli veri bulunmamasıyla beraber kadın erkek oranının eşitsizliğinde mağaradaki iskeletlerin tamamına ulaşılamamış olmasının etkili olduğu yüksek ihtimaldedir.

\section{Sonuç}

$\mathrm{Bu}$ çalışma Kadini Mağarası iskelet topluluğunu oluşturan 90 bireyin demografik özelliklerini konu almışır ve Kadiini topluluğunda bebek ve çocukların (15 yaş altı) ölüm oranı \%37,78; erişkinlerin ölüm oran1 (15 yaş üstü) \%62,22 bulunmuştur. Onarlı yaş aralıklarına göre incelendiğinde toplulukta en yüksek ölüm oranının (dx: \%35,56) 10-19 yaş grubunda olduğu görülmüştür. Toplulukta 0-10 yaş grubu, ölüm oranının $(\% 22,22)$ görece az, ancak yaşam beklentisinin $(19,56$ y1l) en yüksek görüldüğü dönem olarak belirlenmiştir. Ortalama yaşam süresinin (15+ yaş; 25,9 y1l), Anadolu 'nun bazı Kalkolitik ve Tunç Çağı toplumları arasında değerlendirildiğinde düşük olmasıyla birlikte Truva TÇ (Angel, 1986), Oylumhöyük ETÇ (Gökdemir, 2014) ve Seyitömer OTÇ (Özdemir, 2011) toplumlarının değerlerine yakın olduğu tespit edilmiştir. Toplulukta 40-49 yaş grubundaki yaşam beklentisi ( $\left.\mathrm{e}^{0} \mathrm{x}\right) \quad 5 \mathrm{y}$ 1 gibi az bir süredir ve 50 yaş üzerinde yaşayan bireye rastlanmamıştır.

Kadıini topluluğunda kadın erkek oranı eşitsizliğinin $(0,84)$ mağaradaki iskeletlerin tamamına ulaşılamamış olmasından kaynaklandığı yüksek ihtimaldedir.

Kadini'nde kadınların ortalama ömür süresinin (24,5 y1), erkeklerden (26,8 y1l) yaklaşık 2 yıl daha az olduğu bulunmuştur. Diğer yandan hayatta kalma şansinın $(\mathrm{Ix})$ ve yaşam beklentisinin $\left(\mathrm{e}^{0} \mathrm{x}\right), 45$ yaş üstü kadın bireylerde sonlandığ1 ancak erkek bireylerde (Ix: \%11,54; $\mathrm{e}^{0} \mathrm{x}$ : 5 yll) az oranda da olsa devam ettiği kaydedilmiştir.

Sonuç olarak ortalama yaşam uzunluğu, 20 yaş altı bireylerin ölüm oranı $(\% 57,78)$ ve doğumdaki yaşam beklentisi bulgularından Kadinini'nin genç ve büyüyen nüfusa sahip bir topluluk olduğu görülmüştür. Bununla birlikte, Kadiini topluluğunda nüfusun yarısından fazlasının $(\% 67,78) \quad 30$ yaşın altında ölmesinde ve 45 yaş üzerine ulaşabilmiş bireylerin çok az sayıda olmasında bazı Doğu Akdeniz ve Anadolu tarihöncesi toplumlarında olduğu gibi yaşam şartlarının önemli etkisi olduğu; kadın ve erkeklerin ortalama yaşam uzunluğu, hayatta kalma şansı ve yaşam beklentisi bulgularından ise yaşam şartlarından kadınların daha fazla etkilendiği anlaşılmıştır.

\section{Teşekkür}

Kadinini Mağarası kurtarma çalışmalarına başkanlık yapan Alanya Müzesi Müdürü Seher Türkmen'e, çalışmalarda görev alan Alanya Müzesi uzmanları Ferit Coşkun, Faruk Yılmazer, Musa Kabasakal, Gülcan Demir, Belgin Savaş, Mutlu İlhan, Şerife Sezer, Özgül İşlek'e; Süleyman Demirel Üniversitesi Biyospeleoloji 
Araştırmalar Topluluğu (BAT) ve Isparta Uygulamalı Bilimler Üniversitesi Mağara Araştırmaları Topluluğu Başkanı Doç. Dr. Gökhan Aydın'a; Akdeniz Üniversitesi Mağara Araştırmaları Topluluğu (AKÜMAK) üyeleri Buğra Demirkıran, Deniz Can Çay, Hüseyin Üstündağ, Orhan Özdemir, Yiğit Ahmet Sayan ve Anadolu Speleoloji Grubu Derneği (ASPEG) üyeleri Nida Dinç, Alper Utku, Uğur Mumcu Akkaya'ya; Süleyman Demirel Üniversitesi Arama Kurtarma ve İlk Yardım birimi üyeleri Orçun İpekoğlu ve Alper Yaman'a; çalışmalara maddî katkılarından dolayı Alanya Belediyesi Fen İşleri Müdürü Murat Satı'ya; laboratuvar çalışmalarında iskeletlerin üzerindeki kalsitin temizlenmesi için uygun kimyasal çözeltileri hazırlayan ve temizlik işlemlerinin güvenli şekilde yapılmasını üstlenen SDÜ Kimya Bölümü'nden Dr. Öğr. Üyesi Güzide Ertokuş’a teşekkür ederiz.

\section{Kaynakça}

Abay, E. (2011). Preliminary report on the survey project of Çivril, Baklan and Çal plains in the Upper Meander Basin, southwest Anatolia. Ancient Near Eastern Studies, 48,1-87. DOI: 10.2143/ ANES.48.0.2119587

Acsadi, G. Y., ve Nemeski, J. (1970). History of Human Life Span and Mortality. Budapest: Academia Kiado.

Açıkkol, A. (2000). Kücü̈kböyük Eski Tunç Cağ̀ İnsanlarmm Paleoantropolojik Açıdan Incelenmesi (Yayımlanmamış Yüksek Lisans Tezi). Ankara Üniversitesi Sosyal Bilimler Enstitüsü, Ankara.

Açıkkol Yıldırım, A. (2013). Oylum Höyük Toplumunun (Orta Tunç Çağı, Kilis) Paleodemografik Yapısı, ZfWT, 5(3), 35-48.

Açıkkol, A., Yılmaz, H., Baykara, İ, ve Şahin, S. (2004). Kütahya Ağızören Hitit İskeletlerinin Paleoantropolojik Analizi ve Tunç Çă̆1 Anadolu Halkları Arasındaki Yeri. Antropoloji, 17, 1-26. DOI: $10.1501 /$ antro 0000000211

Açıkkol Yıldırım, A., Gözlük Kırmızıoğlu, P., ve Genç, E. (2014). Kuriki Höyük İskeletleri. Arkeometri Sonuclar Toplantısı, 29, 203-215.

Akın, A., ve Ersoy, K. (2012). 2050'ye Doğru Nüfus Bilim ve Yönetim: Sağlık Sistemine Bakıs. İstanbul: TÜSİAD-T/2012-11/533.

Aksu, L. (1998). Dünya'da ve Türkiye'de Nüfus Analizleri. Sosyoloji Konferanslar, 25, 219-311.

Alkan, Y., ve Erkman, A. C. (2013). 2010-2011 Van Kalesi Höyüğü İskeletlerinin Paleodemografik Analizi. Arkeometri Sonuclar Toplantısı, 28, 97-104.

Alpaslan Roodenberg, S. (2008a). The Early Bronze Age Human Remains. J. Roodenberg ve S. Alpaslan-Roodenberg (Ed.) içinde, Life and Death in a Prehistoric Settlement in Northwest Anatolia: The Ilipinar Excavations Vol III (s. 347-360). Nederlands: Institute Voor Her Nabije Oosten.

Alpaslan Roodenberg, S. (2008b). The Neolithic cemetery. The anthropological view, J. Roodenberg ve S. AlpaslanRoodenberg (Ed.) içinde, Life and Death in a Prehistoric Settlement in Northwest Anatolia: The Ilipınar Excavations Vol. III (s. 35-68).
Nederlands: Institute Voor Her Nabije Oosten.

Angel, J. L. (1970). Appendix: Human Skeletal Remains at Karataş. American Journal of Archaeology, 74(3), 253-259. DOI: $\underline{10.2307 / 503101}$

Angel, J. L. (1972). Ecology and population in the Eastern Mediterranean. World Archaeology, 4(1), 88-105. DOI: 10.1080/00438243.1972.9979522

Angel J. L. (1975). Paleoecology, Paleodemography and Health. S. Polgar (Ed.) içinde, Population, ecology and social evolation (s. 167-190). Chicago: The Hague Adine. DOI: $10.1515 / 9783110815603.167$

Angel, J. L. (1984). Health as a crucial factor in the changes from hunting to developed farming in the eastern Mediterranean. M. N. Cohen ve G. J. Armelagos (Ed.) içinde, Paleopathology at the Origins of Agriculture (s. 51-74), Michigan Universiy: Academic Press.

Angel, J. L. (1986). The Physical Identitiy of the Trojans. M. J. Mellink (Ed.) içinde, Troy And Trojan War: A Symposium Held at Bryn Mawr College October 1984 (s. 63-76), USA: Bryn Mawr College Press.

Arman, O. (1991). Elazı̆̆/Aşvankale Yakınçă̆ İskeletlerinin Paleodemografik Açıdan İncelenmesi (Yayımlanmamış Yüksek Lisans Tezi). Ankara Üniversitesi Sosyal Bilimler Enstitüsü, Ankara.

Atamtürk, D. ve Duyar, İ. (2010). Resuloğlu İskeletlerinin (Uğurludağ, Çorum) İskeletlerinin Antropolojik Analizi. Arkeometri Sonuclar Toplantısi, 25, 311-328.

Bass, W. M. (1995). Human Osteology: A Laboratory and Field Manual. Columbia: Missouri Archaeological Society.

Başoğlu, O., ve Şener, T. (2015). Ovaören Erken Tunç Çağı İnsanlar1: Antropolojik Bir İnceleme. HÜSBED, 8(2), 455475. DOI: $10.17218 /$ husbed.15692

Başoğlu, O., Gözlük Kırmızıŏ̆lu, Pehlevan, C., Yiğit, A., ve Erkman, A.C. (2015). The People of Diyarbakir/Salat Tepe in the Chalcolithic nad Middle Bronze Age. Mediterranean Archaeology and Archaeometry, 15(3): 237-247. DOI: 10.5281/ zenodo.32066

Becks, R., ve Polat Becks A. B. (2013). Girmeler Mağaras1-Lykia'da Bir Kalkolitik Dönem Yerleşimi. MAKÜ Sosyal Bilimler Enstitüsü Dergisi, 5(8), 166-183.

Boz, B., ve Hager, L. D. (2013). Karışmış ve dağılmış insan kemiklerinin sosyal davranış kalıplarının anlaşılmasındaki yeri: Çatalhöyük örneği. Arkeometri Sonuclar Toplantısı, 28, 19-30.

Brooks, S., ve Suchey, J. M. (1990). Skeletal age estimation based on the os pubis: a comparison of the Acsadi-Nemeskeri and Suchey-Brooks methods. Human Evolution, 5(3), 227-238. DOI: $10.1007 / \mathrm{BF} 02437238$.

Brothwell, D. R. (1981). Digging Up Bones. London: Oxford University Press.

Buikstra, J. E., ve Ubelaker, D. H. (1994). Standards for data collection from human skeletal remains. Arkansas: Arkansas Archaeological Survey Research Series.

Büyükkarakaya, A. M. (2017). Tepecik-Çiftlik Neolitik 
Topluluğunun Demografik Özellikleri. folklor/ edebiyat, 23(92), 79-98. DOI: $10.22559 /$ folkloredebiyat.2017.57

Caldwell, J.C. (2001). The globalization of fertility behaviour. Population and Development Review, 27, 93-115.

Capuzzo, G., Zanon, M., Dal-Corso, M., Kirleis, W., ve Barceló, J. A. (2018). Highly diverse Bronze Age population dynamics in Central-Southern Europe and their response to regional climatic patterns. PLoS ONE, 13(8), e0200709. DOI: 10.1371/journal.pone.0200709

Carozza, L., Bouby, L., ve Ballut, C. (2006). Un habitat du Bronze moyen à Cournon-d'Auvergne (Puy-de-Dôme): nouvelles données sur la dynamique de l'Âge du Bronze moyen sur la bordure méridionale du Massif central. Bulletin de la Société prébistorique française, 103(3), 535-584.

Caussinus, H., ve Courgeau, D. (2010). Estimer l'âge sans le mesurer en paléodémographie. Population, 65(1), 117-144. DOI: $10.3917 /$ popu.1001.0117

Cullen, T. (1995). Mesolithic mortuary ritual at Franchthi Cave, Greece. Antiquity, 69(263), 270-289. DOI: 10.1017/ $\underline{\mathrm{S} 0003598 \times 00064681}$

Cullen, T. (1999). Scattered Human Bones at Franchthi Cave: Remnants of Ritual or Refuse. P. P. Betancourt, V. Karageorghis, R. Laffineur ve W-D. Niemeier (Ed.) içinde, Meletemata: Studies in Aegean Archaeology Presented to Malcolm H. Wiener as He Enters His 65th Year (s. 165-171). Liege/Texas: AEGAEUM/University of Texas at Austin.

Chamberlain, A. T. (2006). Demography in Archaeology. Cambridge: University Press.

Çırak, A., Çırak, M. T. (2010). Kelenderis/Tiyatro Alanında Yapılan Kazılarda Bulunan İskeletlerin Paleodemografik Analizi. ZfWT, 2(1), 265-281.

Demirel, F. A. (2013). Amorium Aşağ1 Şehir Kilisesi Bebek ve Çocuk İskeletleri. DTCF Dergisi, 53(1), 349-364. DOI: 10.1501/Dtcfder 0000001334

Duyar, İ., Atamtürk, D., Abufaur, B., Özener, E. B. (2017). Sinop Balatlar Kilisesi Kazısından Çıkartılan İskelet ve Mezarlar (MS 13-13'üncü Yüzyıllar). Arkeometri Sonuclar Toplantısı, 32, 119-132.

Erdal, Ö. D. (2012). A Possible Massacre at Early Bronze Age Titriş Höyük, Anatolia. International Journal of Osteoarchaeology, 22(1), 1-21. DOI: $10.1002 /$ oa.1177

Erdal, Ö. D. (2017). Köşk höyük Ortaçağ topluluğunda bebek ve çocuk ölümlülüğ̈ü. Çocuk Sağhğ̀ ve Hastahklar Dergisi, 60(3), 88-103.

Erdal, Ö. D., ve Özbek, M. (2010). Değirmentepe (Malatya) çocuk iskeletlerinin antropolojik analizi. Arkeometri Sonuclar Toplantısi, 25, 279-296.

Erdal, Ö. D., Eroğlu, S., Erdal, Y. S., ve Büyükkarakaya, A. M. (2003). Şaşal/İzmir İskelet Topluluğunun Paleopatolojik Demografik Analizi. Arkeometri Sonuclar Toplantısı, 18, 1-14.

Erdal, Y. S. (1993). İznik Geç Bizans Topluluğunun Demografik Analizi. Arkeometri Sonuclar Toplantısı, 8, 243-257.

Erdal, Y. S. (2000). Eski Anadolu toplumlarında çocuk sağlığı ve hastalıkları. Cocuk Sağh̆̆ğ ve Hastahklar Dergisi, 43, 5-19.

Erdal, Y. S. (2009). Bademağacı Erken Neolitik İnsanları. Arkeometri Sonuclar Toplantısi, 24, 97-118.

Erdal, Y. S. (2011). Tasmasor Yakınçağ Nekropolü ve İskeletlerinin Antropolojik Açıdan Değerlendirilmesi. A. Y. Şenyurt (Ed.) içinde, Tasmasor (s. 329-458). Ankara: Bilgin Kültür Sanat Yayınları.

Erdal, Y. S. (2012). The Population Replacement at Arslantepe: Reflections on the human remains. ORIGINI, XXXIV, 301316.

Erdal, Y. S. (2013). Life and Death at Hakemi Use. O. P. Nieuwenhuyse, R. Benbeck, P. M. M. G. Akkermans ve J. Rogasch (Ed.) içinde, Interpreting The Late Neolithic of Upper Mezopotamia (s. 213-223). Belgium: Brepols Publishers.

Erdal, Y. S., ve Erdal, Ö. D. (2012). Organized Violence in Anatolia: A Retrospective Research on the Injuries from the Neolithic to Early Bronze Age. International Journal of Paleopathology, 2(23), 78-92. DOI: 10.1016/j.ijpp.2012.09.014.

Eryurt, M. A., ve Koç, İ. (2009). Yoksulluk ve çocuk ölümlülüğü: Hanehalkı refah düzeyinin çocuk ölümlülüğü üzerindeki etkisi. Cocuk Sağhğg ve Hastalıklar Dergisi, 52(3), 113-121.

Eshed, V., Hershkovitz, I., ve Goring-Morris, A. N. (2008). A ReEvaluation of Burial Customs in the Pre-Pottery Neolithic $\mathrm{B}$ in Light of Paleodemographic Analysis of the Human Remains from Kfar Hahoresh, Israel. Paléorient, 34(1), 91-103.

Faure, É. (2012). "Hautes terres": l'anthropisation des monts d'Aubrac et du Lévezou (Massif Central, France) durant l'holocène: approche palynologique des dynamiques socio-environnementales en moyenne montagne (Yayımlanmamış Doktora Tezi). Université Toulouse le Mirail, Toulouse II.

Fazekas, I., ve Kosa, F. (1978). Forensic Fetal Osteology. Budapest: Akademiai Kiado.

Gökdemir, S. (2014). Oylum Höyük Erken Tunç Căğ Populasyonunun Paleoantropolojik Analiz̧i (Yayımlanmamış Yüksek Lisans Tezi). Cumhuriyet Üniversitesi Sosyal Bilimler Enstitüsü, Sivas.

Gözlük Kırmızığlu, P. (2005). Karagündüz Toplumunun Paleodemografik Açıdan İncelenmesi. Antropoloji, 20, 75-106. DOI: $10.1501 /$ antro 0000000221

Greulich, W. W. (1957). A comparison of the physical growth and development of American-born and native Japanese children. American Journal of Physical Anthropology, 15(4), 489-515. DOI: 10.1002/ajpa.1330150403

Güleç, E. (1988). Topaklı Popülasyonunun Demografik ve Paleoantropolojik Analizi. Arasstırma Sonuclar Toplantısı, 5(2), 347-357.

Güleç, E. (1989). Panaztepe İskeletlerinin Paleoantropolojik ve Paleopatolojik İncelenmesi. Türk. Arkeoloji Dergisi, 28, 73-95.

Güleç, E. (1994). Akdeniz Bölgesi'nde Bulunan Üç Fosil Kafatası. Belleten, LVIII(223), 531-548.

Güleç, E., Khun, S., Sevim, A., ve Pehlevan, C. (1998). 1996 Y1lı Antalya-Antakya Yüzey Araştırması. Araştırma Sonuclar Toplantısi, 15(2), 247-254.

Güleç, E., Gültekin, T., Özer, İ., Sağır, M., ve Koca Özer, B. 
(2007). A Brief Overview of Bio-Anthropological Analysis of Human Skeletal Remains from Anatolia: Early Neolithic to Ottoman Empire. Human Evolution, 22(3-4), 211-229.

Güleç, E., ve Özer, İ (2009). Dilkaya Ortaçağ İskeletlerinin Paleoantropolojik Analizi. H. Sağlamtimur, E. Abay, Z. Derin, A. Ü. Erdem, A. Batman, F. Dedeoğlu, M. Erdalıran, M. B. Baştürk, ve E. Konakçı (Ed.) içinde, Altan Çilingiroğlu'na Armağan: Yukar Denizin Kiyısında Urartu Kralliğı'na Adanmıs Bir Hayat (s. 319-332). İstanbul: Arkeoloji ve Sanat Yayınlar1.

Hillson, S. W., Larsen, C. S., Boz, B., Pilloud, M. A., Sadvari, J. W., Agarwal, S. C., ... , Haddow, S. D. (2013). The Human Remains I: Interpreting Community Structure, Health, and Diet in Neolithic Çatalhöyük. I. Hodder (Ed) içinde, Humans and Landscapes of Catalhöyük: Reports from the 2000-2008 Seasons (s. 339-396). London: British Institute at Ankara.

Hopa, R. D. (2002). Paleodemography: looking back and thinking ahead, R. D. Hopa, ve J. W. Vaupel (Ed.) içinde, Paleodemography: Age Distributions from skeletal samples (s. 9-28). New York: Cambridge University Press.

Hopa, R. D., Vaupel, J. W. (2002). Paleodemography: Age Distributions from skeletal samples. New York: Cambridge University Press.

Howell, N. (1976). Toward a uniformitarian theory of human paleodemography. R. H. Ward, ve K. M. Weiss (Ed.) içinde, The demographic evolution of human populations (s. 25-40). New York: Academic Press.

Ilan, D., ve Rowan, Y. (2015). The Judean Desert as a Chalcolithic Necropolis. Journal of Mediterranean Archaeology, 28(2), 171194. DOI: $10.1558 /$ imea.v28i2.29530

Johansson, R., ve Horowitz, B. (1986). Estimating Mortality in Skeletal Populations: Influence of the Growth Rate on the Interpretation of Levels and Trends during the Transition to Agriculture. American Journal of Physical Anthropology, 71(2), 233-250. DOI: $10.1002 /$ ajpa.1330710211

Kadini Mağarası Sonuç Raporu (KMSR) (2017). Kadiini Mağarası 2017 Yil Kurtarma Calısmalar Sonuc Raporu. T. C. Alanya Müzesi Müdürlüğü, Antalya.

Knüsel, C., Robb, J., ve Tafuri, M. A. (2016). The Human Skeletal Remains From Scaloria Cave. E. S. Elster, E. Isetti, J. Robb, ve A. Traverso (Ed.) içinde, The Archaeology Of Grotta Scaloria Ritual in Neolithic Southeast Italy (s. 117-130). USA: University of California.

Koca Özer, B., Gültekin T., Özer, İ., Sağır, M., ve Güleç, E. (2008). Longevity in Ancient Anatolian and Turkish Populations from Neolithic to Present. E.B. Bodzsar, ve C. Susanne (Ed.) içinde, Ageing Related Problems in Past and Present Populations (s. 45-58). Biennial Books of EAA.

Konuk Şener, D., ve Ocakç1, A. F. (2014). Yoksulluğun Çocuk Sağlığ1 Üzerine Çok Boyutlu Etkileri. Ankara Sağhlk Hizmetleri Dergisi, 13(1), 57-68. DOI: $10.1501 /$ Ashd 0000000098

Koruyucu, M. M. (2019). Anadolu Erken Tunç Cağ̀ Topluluklarnda A ğız ve Diş Sağhl̆g (Yayımlanmamış Doktora Tezi). Hacettepe Üniversitesi Sosyal Bilimler Enstitüsü, Ankara.

Kökten, K. (1959). Tarsus-Antalya Arası Sahil Şeridi Üzerinde ve Antalya Bölgesinde Yapılan Tarihöncesi Araştırmaları. Türk
Arkeoloji Dergisi, VIII(2), 10-16.

Krogman, W. M., İscan, M.Y. (1986). The Human Skeleton in Forensic Medicine. Springfield, Illinois: Charles C. Thomas.

Larsen, C. S., Hillson, S. W., Boz, B., Pilloud, M. A., Sadvari, J. W., Agarwal, S. C., ... , Knüsel, C.J. (2015). Bioarchaeology of Neolithic Çatalhöyük: Lives and lifestyles of an early farming society in transition. Journal of World History, 28(1), 27-68. DOI: $10.1007 /$ s10963-015-9084-6

Lovejoy, C. O., Meindl, R. S., Pryzbeck, T. R., ve Mensforth, R. P. (1985). Chronolological metamorphosis of the auricular surface of the ilium: A new method for the determination of adult skeletal age at death. American Journal of Physical Anthropology, 68(1), 15-28. DOI: 10.1002/ajpa.1330680103

Maresh, M. M. (1970). Measuraments from roentgenograms. R.W. McCammon (Ed.) içinde, Human Growht and Development (s. 157-200). Springfield: Thomas.

Massa, M. (2014). M.Ö. III. Binyılın Sonunda Batı ve İç Anadolu'da Yıkımlar, Terk Etmeler, Sosyal Yapıda Yeniden Örgütlenme ve İklimsel Değişim. E. Sökmen, ve B. Erciyas (Ed.) içinde, Arkeoloji'de Bölgesel Calıșmalar Sempozyum Bildirileri, Yerleşim Arkeolojisi Serisi 4 (s. 89-123). İstanbul: Ege Yayınlar1

Mays, S. (1998). The Archaeology of Human Bones. Londra: Taylor \& Francis.

Meindl, R. S., Lovejoy, C. O. (1985). Ectocranial suture closure: A revised method fort he determination of skeletal age at death based on the lateral-anterior sutures. American Journal of Physical Anthropology, 68(1), 57-66. DOI: 10.1002/ ajpa.1330680106

Müller, J. (2015). Bronze Age Social Practices: Demography and Economy, Forging Long-Distance Exchange, P. SuchowskaDucke, S. S. Reiter, ve H. Vandkilde (Eds.) içinde, Mobility of Culture in Bronze Age Europe (s. 225-230). Oxford.

Neustupný,E. (2004). Prehistoric Demography, Exploratory Workshop on "Archaeology and Genetics", Toulouse. https://www.kar.zcu. cz/texty/Neustupny PrehistoricDemography'Toulouse.pdf adresinden edinildi (Son Erişim: 14.12.19).

Okyay, P., Atasoylu, G., Meteoğlu, D., Demiröz, H., Çobanoğlu, M., ve Beşer, E. (2006). Aydın İlinde 2004 Yılı Bebek Ölümleri Ve Ölü Doğumlar: Bildirim Sorunları, Tanımlayıcı Özellikleri ve Nedenleri, ADÜ Tip Fakëltesi Dergisi, 7(2), 3-12.

Ökse, A.T. (2005). Eski Çağdan günümüze ölü gömme ve anma gelenekleri. Türk Arkeoloji ve Etnografya Dergisi, 5, 1-8.

Özbek M. (1985). Değirmentepe eski insan topluluklarının demografik ve antropolojik açıdan analizi. Arkeometri Sonuclar Toplantısi, 1, 107-130.

Özbek, M. (1998). Human skeletal remains from Aşı1kl, A Neolithic village near Aksaray, Turkey, G. Arsebük, M. J. Mellink, ve W. Schirmer (Ed.) içinde, Light on the Black Hill (s. 567-579). İstanbul: Ege Yayınlar1.

Özbek, M. (2000). Öküzini İnsanlarının Antropolojik Analizi. Arkeometri Sonuclar Toplantısı, 15, 127-144.

Özbek, M. (2004). Cayönünde İnsan. İstanbul: Arkeoloji ve Sanat Yayinları. 
Özbek, M., ve Erdal, Ö. D. (2006). Anadolu'nun bazı Neolitik ve Kalkolitik topluluklarında bebek ölümleri ve olası nedenleri. Türk Arkeoloji ve Etnografya Dergisi, 6, 41-52.

Özcebe, H. (2006). Çocuk Sağlığını Etkileyen Faktörler. Ç. Güler, ve L. Akın (Ed.) içinde, Halk Sağhtğı: Temel Bilgiler. Ankara: Hacettepe Üniversitesi Yayınları.

Özdemir, S. (2011). Anadolu Tunc Căğ Insan İskeletlerinin Paleodemografik ve Morfometrike Analizi: Kütabya Seyitömer Örneği (Yayımlanmamıs Doktora Tezi). Ankara Üniversitesi Sosyal Bilimler Enstitüsü, Ankara.

Özer, İ., ve Sağır, M. (2003). Dilkaya ve Baž Eski Anadolu Toplumlarnda Uzun Kemiklerin Cevre Ölçülerinden Cinsiyet Tayini. Antropoloji, 16, 87-98. DOI: $10.1501 /$ antro 0000000286

Özer, İ., Sevim, A., Pehlevan, C., ve Arman, O. (1999). Karagündüz Kazısından Çıkarılan İskeletlerin Paleoantropolojik Analizi. Arkeometri Sonuclar Toplantısı, 14, 75-96.

Paine, R. R., Boldsen, J. L. (2002). Linking age-at-death distributions and ancient population Dynamics: a case study. R. D. Hopa, ve J.W. Vaupel (Ed.) içinde, Paleodemography: Age Distributions from Skeletal Samples (s. 169-180), New York: Cambridge University Press.

Robb, J., Elster, E. S., Isetti, E., Knüsel, C. J., Tafuri, M. A., ve Traverso, A. (2015). Cleaning the dead: Neolithic ritual processing of human bone at Scaloria Cave, Italy. Antiquity, 89(343), 39-54. DOI: $10.15184 /$ aqy.2014.35

Sagona, A., ve Zimansky, P. (2015). Arkeolojik Veriler Isı̆ğnda Türkiye'nin En Eski Kültürleri: MÖ 1.000.000-550. İstanbul: Arkeoloji ve Sanat Yayınları.

Sağır, M., Satar, Z., Özer, İ., ve Güleç, E. (2011). Birecik Barajı İlk Tunç Çağı İskeletlerinin Paleoantropolojik Analizi. Arkeometri Sonuclar Toplantısi, 26, 273-290.

Sang, L. (2010). Burial practices of the third Millennium BCE in the Middle Euphrates region: An interpretation of funerary rituals. (Yayımlanmamış Doktora Tezi). Eberhard Karls Universität, Tübingen.

Sevim, A. (1993). Elazı̆g/Tepecike Ortaçă İskeletlerinin Paleodemografik Açıdan Değerlendirilmesi (Yayımlanmamış Doktora Tezi). Ankara Üniversitesi Sosyal Bilimler Enstitüsü, Ankara.

Sevim, A. (2006). Paleoanthropologic Analysis of the human Skeletal Remains From The Yüceören Necropololis. Y. Şenyurt, A. Akçay, ve Y. Kamış (Ed.) içinde, Yüceören. Ankara: Gazi Üniversitesi ARÇED.

Sevim, A., Pehlevan, C., Açıkkol, A., Yılmaz, H., ve Güleç, E. (2002). Karagündüz Erken Demir Çağ1 İskeletleri, Arkeometri Sonuclar Toplantısi, 17, 37-49.

Sevim, A., Açıkkol, A., ve Yılmaz, H. (2005). Çavlum İskeletlerinin Plaoeantropolojik Analizi. I. Uluslararası Dünden Bugüne Eskişehir Sempoฐyumu (12-15 Mayıs 2004) Bildiri Kitabı (s. 337355). Eskişehir: Anadolu Üniversitesi Basımevi.

Scheuer, L., ve Black, S. (2000). Developmental Juvenile Osteology. Elsevier, Academic Press.

Signoli, M., Séguy, I., Biraben, J-N., ve Dutour, O. (2002). Paleodemography and Historical Demography in the Context of an Epidemic: Plague in Provence in the Eighteenth
Century. Population (English Edition), 57(6), 829-854. DOI: $10.2307 / 3246618$

Silibolatlaz Baykara, D. (2019). Tatıka Erken Tunç Çağı (I-II) Ritüel Uygulamalarının Zooarkeolojik Açıdan Değerlendirmesi. Gaziantep University Journal of Social Sciences, 18(1), 549-564. DOI: $10.21547 /$ jss. 482866

Spradley, M.K., Jantz, R.L. (2011). Sex Estimation in Forensic Anthropology: Skull Versus Postcranial Elements. Journal of Forensic Sciences, 56(2), 289-296. DOI: 10.1111/j.15564029.2010.01635.x

Steadman, S. R. (2011). The Early Bronze Age on the Plateau. S. R. Steadman, ve G. McMahon, G. (Ed.) içinde, The Oxford Handbook of Ancient Anatolia. Oxford: Oxford University Press. DOI: $10.1093 /$ oxfordhb/9780195376142.013.0010

Şenyürek, M. S. (1958). Antalya Vilayetinde Öküzini’nde Bulunan Bir İnsan İskeletinin Tetkiki. Belleten, XXII(88), 466-515.

Tezcan, S. (1985). Türkiye'de Bebek ve Cocuk Ölümleri. Ankara: Hacettepe Üniversitesi Tip Fakültesi Halk Sağlığı Anabilim Dalı Yayını (No. 85/26).

Türkiye İstatistik Kurumu (TÜİK) (2012a). Türkiye İstatistik Yillı̆g 2011. TÜİK Yayın No: 3665. Ankara: Türkiye İstatistik Kurumu. http://istmat.info/files/uploads/47802/turkeys statistical yearbook 2011.pdf adresinden edinildi (Son Erişim: 14.12.19)

TÜİK (2012b). Istatistiklerle Kadnn 2012. TÜİK Yayın No: 3904. Ankara: Türkiye İstatistik Kurumu. http://esitizberaberiz. org/wp-content/uploads/2014/02/TUİK-İstatistiklerleKadin-2012.pdf adresinden edinildi (Son Erişim: 14.12.19).

TÜIKK (2016). Demografike Göstergeler, 2000-2025. http://www. tuik.gov.tr/PreIstatistikTablo.do?istab id =1636 adresinden edinildi (Son Erişim: 14.12.19)

Ubelaker, D. H. (1989). Human Skeletal Remains: Excavation, Analysis, Interpretation. Chicago: Smithsonian Instution, Aldire Publishing Company.

Uysal, G. (1995). Oylum Höyük çocuklarının paleopatolojik açıdan incelenmesi. Hacettepe Üniversitesi Edebiyat Fakültesi Dergisi, 12(1-2), 187-206.

Uysal, G. (2006). Gre Virike İskelet Kalıntılarının Paleoantropolojik Analizi. B. Avunç (Ed.) içinde, Hayat Erkanal'a Armağan: Kültürlerin Yansıması (s. 759-762). İstanbul: Homer Yayınevi.

Üstündağ, H., ve Demirel, F. A. (2008). Alanya Kalesi Kazılarında Bulunan İnsan İskeletlerinin Osteolojik Analizi. Türk. Arkeoloji ve Etnoğrafya Dergisi, 8, 79-90.

Workshop of European Anthropologists (WEA) (1980). Recommandations for age and sex diagnoses of skeletons, Journal of Human Evolution, 9(7), 518-549. DOI: 10.1016/00472484(80)90061-5

Webb, P. P. A., ve Suchey, J. M. (1985). Epiphyseal union of the anterior iliac crest and medial clavicle in a modern multiracial sample of American males and females. American Journal of Physical Anthropology, 68(4), 457-466. DOI: 10.1002/ ajpa.1330680402

White, D. T., ve Folkens, P. (2005). Human Osteology Manuel Handbook. USA: Academic Press. 
White, D. T., Black, M. T., ve Folkens, P. (2012). Human Osteology. USA: Academic Press.

Wittwer-Backofen, U. (1988). Palaeodemography of the Early Bronze Age Cemetery of İkiztepe/Samsun. Arastırma Sonuclar Toplantısi, 5(2), 175-190.

Wossink, A. (2009). Challenging Climate Change: Competition and cooperation among pastoralists and agriculturalists in northern Mesopotamia (c. 3000-1600 BC). Leiden: Sidestone Press.

Yaşar, Z. F., Demirel, A., ve Çankaya, A. (2012). Burdur/ Kızılin Mağarası İskeletlerinin Antropolojik Açıdan Değerlendirilmesi. C. Ü. Sosyal Bilimler Enstitüsü Dergisi, 21(2), 129-142.

Yiğit, A., Gözlük Kırmızıoğlu, P., İbiş, R., ve Sevim Erol, A. (2011). Çankırı Salur Erken Tunç Dönemi İnsanları. Arkeometri Sonuclar Toplantısi, 26, 273-290. 